\title{
TINGKAT KONTROL DIRI SISWA DALAM MEMATUHI TATA TERTIB SEKOLAH DI SMAN 1 CANDUANG
}

\author{
Nikmatul Husna \\ Universitas Putra Indonesia YPTK Padang, Indonesia \\ Email: nikmatulhusna11@upiyptk.ac.id
}

\begin{abstract}
Setiap individu memiliki kontrol diri yang berbeda-beda. Ada yang dapat mengontrol diri dengan baik dan ada yang tidak. Penelitian ini beranjak dari kontrol diri memiliki 3 aspek, yaitu: Behavioral Control, Cognitive Control, dan Decisional Control. Penelitian ini bertujuan untuk melihat seberapa besar tingkat kontrol diri siswa dalam mematuhi tata tertib sekolah di SMAN 1 Canduang. Jenis penelitian yang dilakukan adalah penelitian kuantitatif yang bersifat deskriptif dengan menggambarkan, memaparkan, dan menafsirkan kejadian-kejadian sesuai dengan fakta yang diperoleh yang hasilnya berupa angka-angka. Populasi dalam penelitian ini adalah seluruh siswa di SMAN 1 Canduang kelas X, XI, dan XI yang berjumlah 300 orang. Sampel penelitian ini adalah 60 orang yang diambil dengan menggunakan teknik Stratified Proporsional Random Sampling. Data dikumpulkan menggunakan instrumen angket skala Likert. Teknik analisis data menggunakan Statistical Product and Service Solution (SPSS) Versi 16Dari hasil penelitian diperoleh bahwa persentase skor rata-rata untuk behavioral control sebesar 71,15\% dengan standar deviasi 0,84 yang tergolong pada kategori tinggi, persentase skor rata-rata untuk cognitive control sebesar $61,35 \%$ dengan standar deviasi 0,88 yang tergolong pada kategori tinggi, persentase skor rata-rata untuk decisional control sebesar $81,5 \%$ dengan standar deviasi 1,74 yang tergolong pada kategori sangat tinggi. Secara keseluruhan diketahui bahwa persentase rata-rata keseluruhan sebesar 71,33 \% dengan standar deviasi 1,15 yang tergolong pada kategori tinggi. Dapat disimpulkan bahwa siswa SMAN 1 Canduang memiliki tingkat kontrol diri yang tinggi dalam mematuhi tata tertib sekolah.Siswa tersebut mampu mengarahkan dirinya pada tindakan yang tepat yang sesuai dengan lingkungan tempat individu itu berada. Dari hasil penelitian ini diharapkan kepada siswa SMAN 1 Canduang agar bisa tetap mengontrol diri dalam mematuhi tata tertib sekolah dan menjadi lebih baik.
\end{abstract}

\section{Primary Key : Tingkat Kontrol Diri Siswa}

\section{PENDAHULUAN}

Sekolah merupakan lembaga pendidikan formal yang melaksanakan bimbingan, pengajaran, dan latihan dalam rangka membantu siswa agar dapat mengembangkan potensinya, baik yang menyangkut aspek moral-spiritual, intelektual, emosional, maupun sosial. Sebagai lembaga pendidikan, sekolah tentu memiliki peraturan atau tata tertib yang harus dilaksanakan dan dipatuhi oleh setiap personil di sekolah.

Menurut Suryosubrot 2004 tata tertib sekolah adalah ketentuan-ketentuan yang mengatur kehidupan sekolah sehari-hari dan mengandung sanksi terhadap pelanggarnya. Namun, pada kenyataannya semua tidak berjalan dengan lancar, untuk bisa mematuhi tata tertib sekolah, siswa harus mempunyai kontrol diri yang baik sehingga bisa mengendalikan dirinya untuk mematuhi tata tertib sekolah. Pengendalian diri di sini maksudnya adalah pengaturan diri dengan cara memantau perilaku diri sendiri (Ernest R. Hilgard,1991), seseorang dalam perbuatannya dapat menguasai diri dan tetap mengontrol dirinya dari berbagai keinginan yang selalu meluap-luap dan berlebih-lebihan. Dengan begitu perbuatan siswa selalu dalam koridor yang benar sehingga akan tumbuh rasa disiplin siswa untuk selalu mengikuti tata tertib yang berlaku di sekolah. Mematuhi semua tata tertib yang berlaku di sekolah merupakan suatu kewajiban bagi setiap siswa.

Berdasarkan pengamatan penulis di SMAN 1 Canduang fenomena yang terjadi masih ada beberapa siswa yang melanggar tata tertib sekolah, untuk behavioral control siswa membolos saat jam pelajaran berlangsung ia pergi ke kantin, duduk di luar kelas saat pertukaran mata pelajaran, terlambat datang ke sekolah, memakai atribut sekolah tidak lengkap, memakai pakaian sekolah yang tidak rapi, umumnya siswa laki-laki, bajunya dikeluarkan. Selain itu untuk cognitive control terlihat bahwa siswa mudah terpengaruh oleh temannya mau melakukan apa saja ajakan dari temannya, misalnya diajak untuk keluar kelas saat jam pelajaran berlangsung dan duduk di kantin sekolah, meninggalkan sekolah tanpa izin. Sedangkan untuk decisional control ada beberapa siswa mau 
mengikuti apa saja ajakan dari temannya, hal itu dilakukan karena takut kepada temannya tersebut sehingga tidak mampu menolak dan memutuskan untuk tetap mengikuti segala aturan yang ada di sekolahnya.

\section{LANDASAN TEORI}

\subsection{Kontrol Diri}

Kontrol diri adalah kemampuan untuk membimbing tingkah laku sendiri, artinya melakukan pertimbangan terlebih dahulu sebelum memutuskan sesuatu sebelum bertindak. (Chaplin, 2011)

Menurut Michelle Borba, 2008 kontrol diri merupakan kemampuan tubuh dan fikiran untuk melakukan apa yang semestinya dilakukan. Dengan begitu maka individu mampu melakukan apa yang yang seharusnya dilakukan.

Menurut M. Nur Ghufron \& Rini Risnawita, 2010 kontrol diri merupakan kecakapan individu dalam kepekaan membaca situasi diri dan lingkungannya. Sedangkan menurut Ellis, jeanne Ormrod, 2008 kontrol diri merupakan sikap mengendalikan pikiran dan tindakan agar tindakan kita sesuai dengan norma-norma yang benar.

Jadi berdasarkan pendapat-pendapat para ahli di atas, dapat disimpulkan bahwa kontrol diri adalah kemampuan individu untuk mengatur dirinya sendiri untuk melakukan halhal yang sesuai dengan ketentuan yang berlaku sehingga individu mampu menahan dirinya untuk tidak melakukan sesuatu yang dilarang.

\subsection{Jenis- Jenis Kontrol Diri}

Kontrol diri masing-masing individu berbeda-beda tergantung bagaimana individu tersebut mengendalikan dirinya sendiri. Ada tiga jenis kualitas kontrol diri yang ada pada diri individu menurut Daniel Goleman,2000), yaitu :

\section{a. Over control}

Dimana kontrol diri ini dilakukan individu secara berlebihan dan menyebabkan individu banyak menahan diri dalam beraksi terhadap stimulus, ia lebih banyak tidak melakukan tindakan yang mestinya dilakukan.

b. Under control

Merupakan suatu kecenderungan individu untuk melakukan sesuatu dengan bebas tanpa perhitungan yang masak, tanpa memikirkan baik buruk tindakan yang dilakukannya.

c. Appropriate control

Individu ini mampu mengendalikan dirinya sendiri dan tindakan yang dilakukannya sesuai dengan ketentuan yang berlaku.

\subsection{Aspek Kontrol Diri}

Untuk dapat mengontrol diri, maka individu harus mampu mengendalikan fikiran dan tindakan agar tindakan tersebut sesuai dengan norma, menurut M. Nur Ghufron, \& Rini Risnawit, 2010), terdapat 3 aspek, yaitu:

a. Kontrol perilaku (behavioral control)

Kemampuan mengontrol perilaku ini diperinci menjadi dua komponen, yaitu mengatur pelaksanaan (regulated administration) dan kemampuan memodifikasi stimulus (stimulus modifiability). Kemampuan mengatur pelaksanaan merupakan kemampuan individu untuk menentukan siapa yang mengendalikan situasi atau keadaan, dirinya atau diluar dirinya. Kemampuan mengatur stimulus merupakan kemampuan untuk mengetahui bagaimana dan kapan suatu stimulus yang tidak dikehendaki dihadapi.

b. Kontrol kognitif (cognitif control)

Kemampuan individu dalam mengolah informasi yang tidak diinginkan dengan menggabungkan suatu kejadian dalam suatu kerangka kognitif sebagai adaptasi psikologis untuk mengurangi tekanan. Aspek ini terdiri dari dua komponen,yaitu memperoleh informasi (information gain) dan melakukan penilaian (appraisal). Dengan informasi yang dimiliki oleh individu mengenai suatu keadaan yang tidak menyenangkan, individu dapat mengantisipasi keadaan tersebut dengan berbagai pertimbangan. Melakukan penilaian berarti individu 
berusaha menilai dan menafsirkan suatu keadaan atau peristiwa dengan cara memperhatikan segi-segi positif secara subjektif.

c. Mengontrol keputusan (Decisional control)

Merupakan kemampuan seseorang untuk memilih hasil atau suatu tindakan berdasarkan pada sesuatu yang diyakini atau disetujuinya.

\subsection{Tata Tertib Sekolah}

Menurut Suharsimi Arikunto,2008 tata tertib merupakan sesuatu untuk mengatur perilaku yang terjadi pada diri siswa, semua aktifitas dan tingkah laku siswa di sekolah telah diatur dalam peraturan tata tertib sekolah. Menurut Muhammad Rifa'i, 2011 tata tertib sekolah merupakan satu kesatuan yang tidak dapat dipisahkan, sebagai aturan yang berlaku di sekolah agar proses pendidikan dapat berlangsung secara efektif dan efisien.

Sedangkan menurut Suryosubroto, 2004 mengatakan bahwa Tata tertib sekolah ialah ketentuan-ketentuan yang mengatur kehidupan sekolah sehari-hari dan mengandung sanksi terhadap pelanggarnya.

Jadi dapat disimpulkan bahwa tata tertib sekolah merupakan ketentuan-ketentuan yang harus dipatuhi oleh seluruh personil di sekolah dan mengandung sanksi terhadap pelanggarannya. Dengan adanya peraturan sekolah maka akan melatih diri untuk berusaha mengontrol diri agar tidak melanggar aturan-aturan yang ada di sekolah.

\subsection{Unsur-Unsur Peraturan dan Tata Tertib Sekolah}

Tata tertib sekolah berperan sebagai pedoman perilaku siswa, Di samping itu, peraturan juga merupakan salah satu unsur disiplin untuk berperilaku yang memiliki 4 unsur pokok yaitu (Harlock, Elizabeth, 1990):
a. Sebagai pedoman perilaku
b. Konsistensi dalam peraturan tersebut
c. Hukuman untuk pelanggaran peraturan
d. Penghargaan untuk perilaku yang sejalan dengan perilaku yang berlaku.
e.

Berdasarkan pendapat di atas, dapat disimpulkan bahwa ada beberapa unsur tata tertib sekolah, dimana semua unsur tersebut mengatur semua pedoman perilaku, konsistensi, sanksi dan penghargaan.

\subsection{Faktor Yang Menyebabkan Siswa Sering Melanggar Peraturan Sekolah}

Menurut Imam Musbikin, 2012, faktor-faktor yang menyebabkan siswa melanggar tata tertib sekolah adalah:

a. Keadaan atau kondisi lingkungan sekolah, Ini berhubungan dengan kondisi fisik sekolah misalnya tidak ada pagar pembatas atau pagar pembatas yang terlalu rendah, kondisi sekolah yang dekat dengan keramaian, sehingga membuat siswa memiliki kesempatan melanggar tata tertib sekolah.

b. Pola hubungan dengan orang tua yang tidak sehat.

Hal ini berhubungan dengan pola hubungan antara anak dan orang tua, dimana Orang tua cenderung over protective. Anak merasa rendah diri, kurang percaya diri, tidak bergaul dengan teman-temannya. Sedikit saja konflik akan membuat anak tidak nyaman sehingga membolos dari sekolah.

c. Pengalaman negatif di sekolah atau lingkungan.

Persepsi anak terhadap guru yang galak, membuat anak jadi takut dan cemas menghadapi guru dan mata pelajaran bersangkutan. Hal ini menyebabkan anak membolos karena kesal dan takut.

\subsection{Upaya Untuk Menguraangi Pelanggaran Tata Tertib Sekolah}

Cara yang dapat digunakan untuk mengurangi terjadinya pelanggaran yang dilakukan oleh siswa adalah sebagai berikut (Agus Sujanto, 1996):

a. Tidak terlalu beratnya tuntutan sekolah

Anak datang ke sekolah untuk meminta pertolongan, mengembangkan fungsi-fungsi jiwa raganya dalam suasana yang bebas, udara yang segar, dan ruang gerak yang leluasa. 
Karena itu adanya tata tertib yang diterima oleh anak sebagai sesuatu yang membatasi dirinya, justru merupakan penekanan terhadap perkembangannya. Sehingga mereka lebih sering melakukan sesuatu yang mereka senangi walaupun harus melanggar tata tertib sekolah.

b. Mengurangi keketatan berlakunya tata tertib

Dengan menyadari maksud kedatangan anak ke sekolah, biarlah ia menyesuaikan diri seperti yang dapat dilakukannya, tanpa terlalu banyak cara menyesuaikan diri yang harus dilakukan kepadanya, sehingga siswa tersebut akan lebih memahami tata tertib sekolah tersebut dan berusaha mentaatinya.

c. Memberi contoh yang banyak

Dengan memberi contoh, dan mengurangi banyaknya peraturan tata tertib biasanya lebih berhasil. Sebab sifat kodrat manusia selalu meniru sebagian besar apa yang dilakukan oleh manusia-manusia lain yang sekiranya menuntun kemajuan perkembangannya.

d. Menjelaskan maksud dan tujuan tata tertib

Setiap tata tertib yang disertai keterangan yang jelas dan wajar sehingga mudah dimengerti oleh siswa.

e. Tidak obral dengan hukuman

Peraturan tata tertib yang baik adalah peraturan tata tertib yang disertai penjelasan bahwa tata tertib ini berlaku untuk semua kepentingan.

\section{METODOLOGI PENELITIAN}

Penelitian ini dilakukan di SMAN 1 Canduang. Jenis penelitian ini adalah penelitian kuantitatif yang bersifat deskriptif dengan menggambarkan, memaparkan, dan menafsirkan kejadiankejadian sesuai dengan fakta yang diperoleh dan hasilnya berupa angka-angka.

Populasi dalam penelitian ini adalah seluruh siswa di SMAN 1 Canduang kelas X, XI, dan XI yang berjumlah 300 orang. Sampel penelitian ini adalah 60 orang yang diambil dengan menggunakan teknik Stratified Proporsional Random Sampling. Data dikumpulkan menggunakan instrumen angket skala Likert. Teknik analisis data menggunakan Statistical Product and Service Solution (SPSS) Versi 16. Definisi operasional yang dimaksud adalah untuk menjelaskan makna variabel yang sedang diteliti (Riduwan,2015), difinisi operasional yang akan dijelaskan dalam penelitian ini kontrol diri dengan indikator pengukuran menurut M. Nur Ghufron, \& Rini Risnawit,2010 yaitu: 1. Behavioral control, 2. Cognitive control, 3. Decisional control.

\section{HASIL DAN PEMBAHASAN}

\section{Hasil Uji Validitas}

Pada penelitian ini penulis menggunakan jenis validitas empiris dan validasi isi. Validasi empiris yaitu suatu instrumen dinyatakan valid setelah dilakukan uji coba instrumen. Dimana hasil validasi empiris menunjukkan bahwa terdapat beberapa item valid dan hanya sedikit item yang tidak valid. Jadi item yang tidak valid tersebut penulis keluarkan dan tidak penulis ikutkan untuk pengujian selanjutnya.

\section{Deskripsi Hasil Penelitian}

Gambaran kontrol diri siswa dalam mematuhi tata tertib sekolah di SMAN 1 Canduang untuk masing-masing indikator dapat dilihat sebagai berikut:

\section{Tabel 1}

Kontrol diri siswa SMAN 1 Canduang

\begin{tabular}{|c|l|c|c|c|c|}
\hline \multirow{2}{*}{ No } & \multirow{2}{*}{ Aspek kontrol diri } & \multicolumn{2}{|c|}{ Skor } & \multirow{2}{*}{ SD } & \multirow{2}{*}{ Kategori } \\
\cline { 3 - 4 } & Mean & \% & & Tinggi \\
\hline 1 & Behavioral control & 3,56 & 71,15 & 0,84 & Tinggi \\
\hline 2 & Cognitive control & 3,09 & 61,35 & 0,88 & Sangat tinggi \\
\hline 3 & Decisional control & 4,08 & 81,5 & 1,74 & Tinggi \\
\hline Rata-rata keseluruhan & $\mathbf{3 , 5 7}$ & $\mathbf{7 1 , 3 3}$ & $\mathbf{1 , 1 5}$ & \\
\hline
\end{tabular}

Dari tabel diatas diketahui bahwa presentase skor rata-rata untuk behavioral control sebesar $71,15 \%$ dengan standar deviasi 0,84 yang tergolong pada kategori tinggi, persentase skor 
rata-rata untuk cognitive control sebesar $61,35 \%$ dengan standar deviasi 0,88 yang tergolong pada kategori tinggi, persentase skor rata-rata untuk decisional control sebesar $81,5 \%$ dengan standar deviasi 1,74 yang tergolong pada kategori sangat tinggi. Pada tabel keseluruhan diketahui bahwa persentase rata-rata keseluruhan sebesar 71,33 \% dengan standar deviasi 1,15 yang tergolong pada kategori tinggi maka dapat disimpulkan pada umumnya siswa SMAN 1 Canduang memiliki kontrol diri yang tinggi dalam mematuhi tata tertib sekolah.

Gambaran lebih rinci berkenaan dengan tingkat kontrol diri siswa dalam mematuhi tata tertib sekolah di SMAN 1 Canduang dapat di lihat pada tabel berikut:

\section{A. Behavioral control}

Kontrol diri siswa dalam behavioral control terdiri atas 2 deskriptor, yaitu: kemampuan mengatur pelaksanaan, dan kemampuan mengatur stimulus/respon. Data yang diperoleh yaitu:

\section{Kemampuan mengatur pelaksanaan}

Tabel 2

Kemampuan mengatur pelaksanaan

\begin{tabular}{|c|l|c|c|c|c|c|c|}
\hline \multirow{2}{*}{ No Item pernyataan } & \multirow{2}{*}{ SD } & \multirow{2}{*}{ Range } & \multicolumn{2}{|c|}{ Skor } \\
\cline { 8 - 9 } & & $\begin{array}{c}\text { Mer } \\
\text { an }\end{array}$ & \% & & & Max & Min \\
\hline 1. & Datang ke sekolah tepat waktu & 4,6 & 92 & 0,7 & 2 & 5 & 3 \\
\hline 2. & Memakai atribut sekolah dengan lengkap & 4 & 80 & 1 & 4 & 5 & 1 \\
\hline 3 & $\begin{array}{l}\text { Senang meminta izin ke luar kelas saat } \\
\text { proses belajar berlangsung }\end{array}$ & 3 & 61 & 0,8 & 4 & 5 & 1 \\
\hline 4 & $\begin{array}{l}\text { Memilih keluar kelas jika tidak menyukai } \\
\text { guru / mata pelajaran tertentu }\end{array}$ & 3,7 & 73 & 0,9 & 3 & 5 & 2 \\
\hline & Rata-rata keseluruhan & $\begin{array}{c}\mathbf{3 , 8} \\
\mathbf{2}\end{array}$ & $\begin{array}{c}\mathbf{7 6} \\
\mathbf{5}\end{array}$ & $\begin{array}{c}\mathbf{0 , 8} \\
\mathbf{5}\end{array}$ & $\mathbf{4}$ & $\mathbf{5}$ & $\mathbf{1}$ \\
\hline
\end{tabular}

Berdasarkan tabel di atas diketahui bahwa persentase skor rata- rata keseluruhan untuk deskriptor kemampuan mengatur pelaksanaan 76,5\% dengan standar deviasi 0,85. Maka dapat disimpulkan siswa SMAN 1 Canduang memiliki kemampuan dalam mengatur pelaksanaan yang tergolong pada kategori tinggi.

\section{Kemampuan mengatur stimulus/respon}

Tabel 3

Kemampuan mengatur stimulus/respon

\begin{tabular}{|c|l|c|c|c|c|c|c|}
\hline \multirow{2}{*}{ No } & \multicolumn{2}{|}{ Item Pernyataan } & \multicolumn{2}{|c|}{ Skor } & \multirow{2}{*}{ SD } & Range & \multicolumn{2}{|c|}{ Skor } \\
& & Mean & \% & & Max & Min \\
\hline 1. & $\begin{array}{l}\text { Berusaha untuk mematuhi tata tertib } \\
\text { sekolah walaupun teman saya } \\
\text { mengajak untuk melanggarnya }\end{array}$ & 4,3 & 85 & 0,8 & 2 & 5 & 3 \\
\hline 2. & $\begin{array}{l}\text { Berusaha untuk tetap berada di kelas } \\
\text { walaupun guru tidak masuk kelas }\end{array}$ & 3,4 & 68 & 0,8 & 3 & 5 & 2 \\
\hline 3 & $\begin{array}{l}\text { Tidak mengulangi bentuk-bentuk } \\
\text { pelanggaran yang pernah dilakukan }\end{array}$ & 3,4 & 68 & 1 & 4 & 5 & 1 \\
\hline 4 & $\begin{array}{l}\text { Mengikuti teman yang melanggar tata } \\
\text { tertib sekolah }\end{array}$ & 3,8 & 76 & 0,8 & 2 & 5 & 3 \\
\hline 5 & $\begin{array}{l}\text { Takut keluar kelas jika ada kepala } \\
\text { sekolah atau guru piket }\end{array}$ & 1,6 & 32 & 0,8 & 3 & 4 & 1 \\
\hline & Rata-rata keseluruhan & $\mathbf{3 , 3}$ & $\mathbf{6 5}$, & $\mathbf{0 , 8 4}$ & $\mathbf{2}$ & $\mathbf{5}$ & $\mathbf{3}$ \\
\hline
\end{tabular}

Berdasarkan tabel di atas diketahui bahwa persentase skor rata- rata keseluruhan untuk deskriptor kemampuan mengatur stimulus/respon 65,8\% dengan standar deviasi 0,84. Maka dapat disimpulkan 
siswa SMAN 1 Canduang memiliki kemampuan dalam mengatur stimulus/respon yang tergolong pada kategori tinggi.

\section{B. Cognitive control}

Kontrol diri siswa dalam cognitive control terdiri atas 2 deskriptor, yaitu: memperoleh informasi, dan melakukan penilaian. Data yang diperoleh yaitu:

\section{Memperoleh informasi}

Tabel 4

Memperoleh informasi

\begin{tabular}{|c|c|c|c|c|c|c|c|}
\hline \multirow{2}{*}{ No } & \multirow{2}{*}{ Item pernyataan } & \multicolumn{2}{|c|}{ Skor } & \multirow{2}{*}{ SD } & \multirow{2}{*}{ Range } & \multicolumn{2}{|c|}{ Skor } \\
\hline & & Mean & $\%$ & & & Max & Min \\
\hline 1. & $\begin{array}{l}\text { Membaca bentuk sanksi yang } \\
\text { diberikan jika melanggar tata tertib } \\
\text { sekolah }\end{array}$ & 2,4 & 48 & 0,8 & 4 & 5 & 1 \\
\hline 2. & $\begin{array}{l}\text { Mendengarkan informasi yang } \\
\text { diberikan tentang tata tertib sekolah }\end{array}$ & 3,4 & 68 & 0,9 & 3 & 5 & 2 \\
\hline 3 & $\begin{array}{l}\text { Tidak menyimpan bentuk tata tertib } \\
\text { sekolah }\end{array}$ & 1,7 & 34 & 0,8 & 2 & 3 & 1 \\
\hline 4 & $\begin{array}{l}\text { Tidak mempedulikan informasi } \\
\text { yang diberikan guru mengenai tata } \\
\text { tertib sekolah }\end{array}$ & 3,4 & 67 & 0,6 & 3 & 5 & 2 \\
\hline 5 & $\begin{array}{l}\text { Tidak menghiraukan informasi } \\
\text { tentang tata tertib yang diberikan }\end{array}$ & 3,5 & 69 & 0,7 & 3 & 5 & 2 \\
\hline & Rata-rata keseluruhan & 2,88 & 57,2 & $\begin{array}{c}0,7 \\
6\end{array}$ & 3 & 5 & 2 \\
\hline
\end{tabular}

Dari tabel di atas diketahui persentase skor rata- rata keseluruhan untuk deskriptor kemampuan memperoleh informasi 57,2 \% dengan standar deviasi 0,76. Maka dapat disimpulkan siswa SMAN 1 Canduang memiliki kemampuan dalam memperoleh informasiyang tergolong pada kategori sedang

\section{Melakukan penilaian}

Tabel 5

Melakukan penilaian

\begin{tabular}{|c|c|c|c|c|c|c|c|}
\hline \multirow[b]{2}{*}{ No } & \multirow[b]{2}{*}{ item pernyataan } & \multicolumn{2}{|c|}{ Skor } & \multirow[b]{2}{*}{ SD } & \multirow[b]{2}{*}{ Range } & \multicolumn{2}{|c|}{ Skor } \\
\hline & & $\begin{array}{c}\text { Mea } \\
\mathbf{n}\end{array}$ & $\%$ & & & Max & Min \\
\hline 1. & $\begin{array}{l}\text { AKan memikirkan manfaat yang } \\
\text { diperoleh ketika mematuhi tata } \\
\text { tertib sekolah }\end{array}$ & 4 & 80 & 0,7 & 3 & 5 & 2 \\
\hline 2. & $\begin{array}{l}\text { Hukuman yang diberikan adalah } \\
\text { konsekuensi dari perbuatan sendiri }\end{array}$ & 2,4 & 48 & 1,3 & 4 & 5 & 1 \\
\hline 3 & $\begin{array}{l}\text { Melakukan sesuatu yang melanggar } \\
\text { peraturan tanpa memikirkan } \\
\text { akibatnya }\end{array}$ & 3,3 & 65 & 0,8 & 3 & 5 & 2 \\
\hline 4 & $\begin{array}{l}\text { Melakukan pelanggaran terhadap } \\
\text { tata tertib sekolah karena mudah } \\
\text { terpengaruh olehteman }\end{array}$ & 3,5 & 69 & 1,2 & 4 & 5 & 1 \\
\hline & Rata-rata keseluruhan & 3,3 & 65,5 & 1 & 4 & 5 & 1 \\
\hline
\end{tabular}

Berdasarkan tabel di atas diketahui persentase skor rata- rata keseluruhan untuk deskriptor melakukan penilaian $65,5 \%$ dengan standar deviasi 1 . Maka dapat disimpulkan 
siswa SMAN 1 Canduang memiliki kemampuan dalam melakukan penilaian yang tergolong pada kategori tinggi.

\section{Decisional control}

Kontrol diri siswa dalam decisional control terdiri atas 2 deskriptor, yaitu: memilih tindakan yang akan dilakukan, dan berani menerima konsekuensi dari tindakan yang telah dilakukan. Data yang diperoleh yaitu:

\section{Memilih tindakan yang akan dilakukan}

Tabel 6

Memilih tindakan yang akan dilakukan

\begin{tabular}{|c|c|c|c|c|c|c|c|}
\hline \multirow[b]{2}{*}{$\begin{array}{l}\mathbf{N} \\
\mathbf{0}\end{array}$} & \multirow[b]{2}{*}{ Item pernyataan } & \multicolumn{2}{|c|}{ Skor } & \multirow[b]{2}{*}{ SD } & \multirow[b]{2}{*}{ Range } & \multicolumn{2}{|c|}{ Skor } \\
\hline & & $\begin{array}{c}\text { Mea } \\
\mathbf{n}\end{array}$ & $\%$ & & & $\operatorname{Max}$ & $\begin{array}{c}\text { Mi } \\
\text { n }\end{array}$ \\
\hline 1. & $\begin{array}{l}\text { Tetap berusaha mematuhi tata tertib sekolah } \\
\text { walaupun banyak teman yang melanggar } \\
\text { tata tertib tsb }\end{array}$ & 4,3 & 86 & 0,8 & 2 & 5 & 3 \\
\hline 2. & $\begin{array}{l}\text { Akan tetap berada di sekolah walaupun } \\
\text { banyak teman yang cabut }\end{array}$ & 3 & 60 & 1 & 4 & 5 & 1 \\
\hline 3 & $\begin{array}{l}\text { Akan menjadikan pengalaman sebagai } \\
\text { pelajaran untuk kedepannya }\end{array}$ & 4,7 & 94 & 0,5 & 2 & 5 & 3 \\
\hline 4 & Memilihcabut ketika tidak diizinkan pulang & 4,7 & 94 & 0,7 & 3 & 5 & 2 \\
\hline 5 & $\begin{array}{l}\text { Akan membolos jika terlambat datang ke } \\
\text { sekolah }\end{array}$ & 4,3 & 87 & 1,1 & 4 & 5 & 1 \\
\hline 6 & $\begin{array}{l}\text { Akan berbohong untuk menghindari } \\
\text { hukuman }\end{array}$ & 4,2 & 83 & 1 & 4 & 5 & 1 \\
\hline 7 & $\begin{array}{l}\text { Akan menghindari guru piket atau guru } \\
\text { lainnya ketika melanggar peraturan sekolah }\end{array}$ & 2,9 & 58 & 1,1 & 4 & 5 & 1 \\
\hline & Rata-rata keseluruhan & 4,01 & $\begin{array}{c}80, \\
2\end{array}$ & $\begin{array}{c}\mathbf{0 , 8} \\
8\end{array}$ & 4 & 5 & 1 \\
\hline
\end{tabular}

Berdasarkan tabel di atas diketahui bahwa persentase skor rata- rata keseluruhan untuk dsekriptor memilih tindakan yang akan dilakukan 80,2 \% dengan standar deviasi 0,88. Maka dapat disimpulkan siswa SMAN 1 Canduang memiliki kemampuan dalam memilih tindakan yang akan dilakukan yang tergolong pada kategori sangat tinggi

\section{Berani menerima konsekuensi dari tindakan yang telah dilakukan}

Tabel 7

Berani menerima konsekuensi dari tindakan yang telah dilakukan

\begin{tabular}{|c|c|c|c|c|c|c|c|}
\hline \multirow[b]{2}{*}{ No } & \multirow[b]{2}{*}{ Item Pernyataan } & \multicolumn{2}{|c|}{ Skor } & \multirow[b]{2}{*}{ SD } & \multirow[b]{2}{*}{ Range } & \multicolumn{2}{|c|}{ Skor } \\
\hline & & Mean & $\%$ & & & $\begin{array}{c}\text { Ma } \\
\mathbf{x}\end{array}$ & Min \\
\hline 1. & $\begin{array}{l}\text { Meneima hukuman yang diberikan jika } \\
\text { melanggar tata tertib sekolah }\end{array}$ & 4,4 & 88 & 0,7 & 2 & 5 & 3 \\
\hline 2. & $\begin{array}{l}\text { Menerima guru memarahi jika melanggar } \\
\text { tata tertib sekolah }\end{array}$ & 4,3 & 86 & 0,7 & 2 & 5 & 3 \\
\hline 3 & $\begin{array}{l}\text { Berusaha menutupi kesalahan ketika } \\
\text { melakukan pelanggaran }\end{array}$ & 3,8 & 77 & 1 & 3 & 5 & 2 \\
\hline 4 & $\begin{array}{l}\text { Menghindar untuk menjalankan hukuman } \\
\text { yang diberikan }\end{array}$ & 4,1 & 81 & 0,9 & 2 & 5 & 3 \\
\hline 5 & $\begin{array}{l}\text { Menjalani hukuman yang diberikan } \\
\text { dengan terpaksa }\end{array}$ & 4,1 & 82 & 1 & 3 & 5 & 2 \\
\hline 6 & $\begin{array}{l}\text { Hukuman yang diberikan terlalu } \\
\text { memberatkan }\end{array}$ & 4,2 & 83 & 0,9 & 2 & 5 & 3 \\
\hline & Rata-rata keseluruhan & 4,15 & 82, & 0,8 & 2 & 5 & 3 \\
\hline
\end{tabular}




\section{\begin{tabular}{|l|l|l|l|l|l|l|}
\hline & & 8 & 6 & & & \\
\hline
\end{tabular}}

Berdasarkan tabel di atas diketahui bahwa persentase skor rata- rata keseluruhan untuk indikator berani menerima konsekuensi dari tindakan yang telah dilakukan 82,8 \% dengan standar deviasi 0,86. Maka dapat disimpulkan pada umumnya siswa SMAN 1 Canduang memiliki keberanian dalam menerima konsekuensi dari tindakan yang telah dilakukan yang tergolong pada kategori sangat tinggi.

Untuk mengetahui deskripsi hasil penelitian tentang tingkat kontrol diri siswa dalam mematuhi tata tertib sekolah di SMAN 1 Canduang, maka penulis jabarkan hasil penelitian sbb:

Tabel 8

Hasil Pengolahan SPSS 16 Deskriptif Statistic Tingkat Kontrol Diri Siswa dalam Mematuhi Tata Tertib Sekolah di SMAN 1 Canduang

\begin{tabular}{|l|c|}
\hline \multicolumn{1}{|c|}{ Statistik } & Kontrol_Diri \\
\hline $\mathrm{N}$ Valid & 60 \\
Missing & 0 \\
Mean & 71,33 \\
Std. Deviation & 4.415 \\
Range & 18 \\
Minimum & 63 \\
Maximum & 81 \\
\hline
\end{tabular}

Dari tabel di atas diketahui bahwa, skor tertinggi yang diperoleh siswa adalah 81, sedangkan skor terendah adalah 63, dengan standar deviasi 4,415. Secara keseluruhan kontrol diri siswa berada pada kategori tinggi dengan rata-rata (mean) 71,33

\section{KESIMPULAN}

Berdasarkan hasil penelitian yang telah dilaksanakan di SMAN 1 Canduang, dan setelah dilakukan pengolahan data, tingkat kontrol diri siswa dalam behavioral control memiliki persentase rata-rata $71,15 \%$ dengan standar deviasi 0,84 yang tergolong pada kategori tinggi. Tingkat kontrol diri siswa dalam cognitive control memiliki persentase rata-rata $61,35 \%$ dengan standar deviasi 0,88 yang tergolong pada kategori tinggi. Sedangkan tingkat kontrol diri siswa dalam decisional control memiliki persentase rata-rata 81,5\% dengan standar deviasi 1,74 yang tergolong pada kategori sangat tinggi.

Tingkat kontrol diri siswa SMAN 1 Canduang secara keseluruhan memiliki persentase rata-rata sebesar 71,33\% dengan standar deviasi 1,15 yang tergolong pada kategori tinggi, sehingga siswa SMAN 1 Canduang memiliki tingkat kontrol diri yang tinggi dalam mematuhi tata tertib sekolah.

SARAN 


\section{DAFTAR PUSTAKA}

[1]...Agus Sujanto, 1996. Psikologi Perkembangan. Jakarta; Rineka Cipta, p.98-113

[2]...Chaplin, Kamus lengkap psikologi, Jakarta : PT Raja Grafindo, 2011), h. 451

[3]...Daniel Goleman. 2000. Kecerdasan Emosional, Jakarta; PT Gramedia Pustaka Utama, p. 181

[4]...Ellis, jeanne Ormrod.2008. Psikologi Pendidikan, Jakarta: PT Gelora Aksara Pratama, p. 12

[5]...Ernest R. Hilgard, 1991 .Pengantar Psikologi, Jakarta; Erlangga, p.307

[6]...Harlock, Elizabeth,1990. Psikologi Perkembangan Suatu Pendekatan Sepanjang Rentangn Kehidupan, Jakarta; Erlangga, p. 84

[7]...Imam Musbikin, 2012. Mengatasi Anak Mogok Sekolah + Malas Belajar, Jokjakarta: Laksana, p.30-31

[8]...Michelle Borba.2008.Membangun Kecerdasan Moral, Jakarta, Gramedia Pustaka Utama, p. 112

[9]...M. Nur Ghufron, \& Rini Risnawit,2010. Teori-teori Psikologi,Yogyakarta:Ar-Ruzz Media, p.21-31

[10]...Muhammad Rifa'i, 2011.Sosiologi Pendidikan, Yogyakarta,: Ar-Ruzz Media,p. 139141

[12]...Nur Lailatul Muniroh, 2013. Hubungan antara kontrol diri dan perilaku disiplin pada santri di pondok pesantren, Yogyakarta

[13]...Sugiyono, 2010. Metode Penelitian Kuantitatif Kualitatif dan $R \&$ \& D. Bandung: Alfabeta,p. 125

[14]...SuharsimiArikunto, 2008. Manajemen Pengajaran Secara Manusiawi, Jakarta, Bumi Aksara, p122-134

[15]...Suryosubroto, 2004. Manajemen pendidikan di sekolah, Jakarta,: PT Rineka Cipra, p.81

[16]...Yuni N Ur Dinasyari, 2017. Penelitian tingkat ketaatan siswa terhadap peraturan di SMK Muhammadiyah 2 jatinom, Surakarta 